\title{
Characterizations of Chitosan-Based Polymer Electrolyte Photovoltaic Cells
}

\author{
M. H. Buraidah, L. P. Teo, S. R. Majid, R. Yahya, R. M. Taha, and A. K. Arof \\ Centre for Ionics University of Malaya, Physics Department, University of Malaya, 50603 Kuala Lumpur, Malaysia \\ Correspondence should be addressed to A. K. Arof, akarof@um.edu.my
}

Received 7 December 2009; Accepted 11 March 2010

Academic Editor: Gaetano Di Marco

Copyright $\odot 2010$ M. H. Buraidah et al. This is an open access article distributed under the Creative Commons Attribution License, which permits unrestricted use, distribution, and reproduction in any medium, provided the original work is properly cited.

The membranes 55 wt.\% chitosan- 45 wt. $\% \mathrm{NH}_{4} \mathrm{I}, 33$ wt. $\%$ chitosan- 27 wt. $\% \mathrm{NH}_{4} \mathrm{I}-40$ wt. $\%$ EC, and 27.5 wt. $\%$ chitosan22.5 wt. $\% \mathrm{NH}_{4} \mathrm{I}-50$ wt. $\%$ buthyl-methyl-imidazolium-iodide (BMII) exhibit conductivity of $3.73 \times 10^{-7}, 7.34 \times 10^{-6}$, and $3.43 \times$ $10^{-5} \mathrm{~S} \mathrm{~cm}^{-1}$, respectively, at room temperature. These membranes have been used in the fabrication of solid-state solar cells with configuration ITO/ $\mathrm{TiO}_{2}$ /polymer electrolyte membrane/ITO. It is observed that the short-circuit current density increases with conductivity of the electrolyte. The use of anthocyanin pigment obtained by solvent extraction from black rice and betalain from the callus of Celosia plumosa also helps to increase the short-circuit current.

\section{Introduction}

Solid polymer electrolytes are being utilized in the fabrication of solid-state photoelectrochemical (PEC) cells. The configuration of such cells in general is photoactive electrode/polymer electrolyte/counter electrode. The polymer electrolyte basically consists of polymer and salt together with a redox couple. Examples include polyethylene oxide (PEO)-KI-I $\mathrm{I}_{2}[1,2]$, chitosan-PEO-NH $\mathrm{I}_{4}-\mathrm{I}_{2}$ [3], PEO$\mathrm{NH}_{4} \mathrm{I}-\mathrm{I}_{2}$ [4], and polyvinylchloride (PVC) $-\mathrm{LiClO}_{4}$ [5]. In order to enhance performance of the PEC cell, plasticizers have been used either as an additive or as a solvent or cosolvent. Examples include PEO-poly(vinylidene fluoride) (PVDF)-LiI-I ${ }_{2}$ [6] which were dissolved in propylene carbonate and dimethoxyethane, polyvinyl pyrrolidone (PVP)-polyethylene glycol (PEG)-KI-I 2 [7], PEOethylene carbonate (EC)-propylene carbonate (PC)-KI-I [8], and poly(epichlorohydrin-co-ethylene oxide) (P(EPIEO))-poly(ethylene glycol) methyl ether (P(EGME))-NaI- $\mathrm{I}_{2}$ [9].

The photoactive electrode is usually a semiconducting material, can be inorganic or organic, and serves to produce photoelectrons when illuminated. The most common inorganic semiconducting material used is $\mathrm{TiO}_{2}$ [10-13]. Other inorganic semiconductor materials include CdSe [14], ZnTe
[3], and ZnSe [15]. Organic semiconductor materials include the polythiophenes. Examples are poly(3-methylthiophene) (P3MT) [2] and poly[3-(4-octylphenyl)thiophene] (POPT) [16]. Counter electrodes that have been used include graphite [5] and platinum (Pt) [17-20]. A large difference in the Fermi levels between the photoanode and counter electrode under illumination will exhibit a large potential difference and thus will enable a larger current to be delivered by the device.

Types of redox couples or mediators include $\mathrm{I}^{-} / \mathrm{I}_{3}{ }^{-}[21-$ 24], 5-mercapto-1-methyltetrazole cesium salt (CsT)/di-5(1-methyltetrazole) $\left(\mathrm{T}_{2}\right) \quad[14], \mathrm{Fe}^{3+} / \mathrm{Fe}^{2+}[25], \mathrm{Co}(\mathrm{II} / \mathrm{III})$ [26], $\mathrm{OH}^{-} / \mathrm{O}_{2}{ }^{-}$, and $\mathrm{S} / \mathrm{S}^{2-}$ [27]. The performance of these PEC cells can be improved by soaking the photoactive electrode with a suitable dye material. When the PEC cell is illuminated, electrons in the dye are excited and injected into the conduction band of the semiconductor photoelectrode. The dye-sensitizer is thereby oxidized. The mediator $\left(\mathrm{I}^{-} / \mathrm{I}_{3}{ }^{-}\right.$couple $)$in the electrolyte regenerates the oxidized dye producing photocurrent and photovoltage in the cell. Examples of dye materials are $\mathrm{Ru}\left(4,4^{\prime}\right.$-dicarboxylic

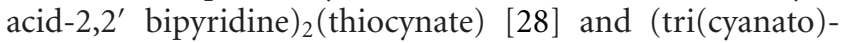
$2,2^{\prime} 2^{\prime \prime}$-terpyridyl-4,4' $4^{\prime \prime}$-tricarboxylate) $\mathrm{Ru}(\mathrm{II})$ [29]. Natural dyes are also being used in dye-sensitized solar cells (DSSCs). These include anthocyanin [30], chlorophyll [31], and 
carotenoid [32]. The photovoltaic performance of a solidstate DSSC may be explained as follows [33]:

$$
\begin{gathered}
D / \mathrm{PE}+h v \longrightarrow D^{*}, \\
D^{*} / \mathrm{PE} \longrightarrow D^{+} / \mathrm{PE}+e^{-} / \mathrm{PE}, \\
M^{+}+e^{-} / \mathrm{CE} \longrightarrow M, \\
D^{+} / \mathrm{PE}+M \longrightarrow D / \mathrm{PE}+M^{+} .
\end{gathered}
$$

Here $D$ is the dye, PE is photoelectrode, CE is counter electrode, and $M$ is redox couple or mediator. In this work, polymer electrolytes consisting of chitosan and $\mathrm{NH}_{4} \mathrm{I}$ with ethylene carbonate (EC) as plasticizer and ionic liquid (IL) as ionic dopant were prepared and used in $\mathrm{TiO}_{2} / \mathrm{ITO}$ cells. Anthocyanin, a natural pigment that was extracted from black rice, and betalain that was extracted from callus of Celosia plumosa (locally known as balong ayam) were used as the material to enhance electron injection into the conduction band of the photoelectrode.

\section{Experimental}

Details of electrolyte preparation can be found in previous works $[34,35]$. Conductivity of the electrolytes was calculated using the equation

$$
\sigma=\frac{d}{R_{b} A}
$$

where $\sigma$ is conductivity, and $A$ and $d$ are area and thickness of the electrolyte film, respectively. $R_{b}$ is the bulk resistance which is derived from the high-frequency intercept on the Cole-Cole plots. The impedance of the samples was measured using the HIOKI 3531-01 LCR Hi-Tester in the frequency range from $50 \mathrm{~Hz}$ to $1 \mathrm{MHz}$ from room temperature to $343 \mathrm{~K}$. For solar cell application, the electrolyte was added with some iodine crystals, $\mathrm{I}_{2}$ (10\% of salt amount) to provide the redox couple $\mathrm{I}^{-} / \mathrm{I}_{3}{ }^{-}$.

The anthocyanin pigment was extracted from black rice grains and betalain from callus of Celosia plumosa. Black rice and callus were immersed in 95\% ethanol and methanol solution, respectively. The pigment solutions were kept at room temperature in the dark for 24 hours. Filtration was done to remove the residues and the $\mathrm{pH}$ of the dye was adjusted accordingly by adding hydrochloric acid. Procedure for callus production can be found in [36].

An indium tin-oxide $(\mathrm{ITO})$ glass $\left(2.5 \times 2.5 \mathrm{~cm}^{2}\right)$ with sheet resistance of $5 \Omega \mathrm{cm}^{-2}$ was cleaned with distilled water and acetone. A part of the ITO layer was covered and the active area of the ITO layer is about $0.16 \mathrm{~cm}^{2} . \mathrm{TiO}_{2}$ paste (JGC Catalysts \& Chemicals Ltd) was doctor-bladed on the ITO substrate to form the photoactive cathode. The $\mathrm{TiO}_{2}$ layer was then heated at $773 \mathrm{~K}$ for 1 hour. The thickness of the film was controlled using adhesive tape of thickness $100 \mu \mathrm{m}$. After cooling to $373 \mathrm{~K}$, the $\mathrm{TiO}_{2}$ electrode was immersed in an anthocyanin solution for 24 hours and the ITO sheet resistance of $11 \Omega \mathrm{cm}^{-2}$ was obtained. The photoelectrode was washed with water to remove impurities and then with ethanol to remove trapped water from the initial washing.

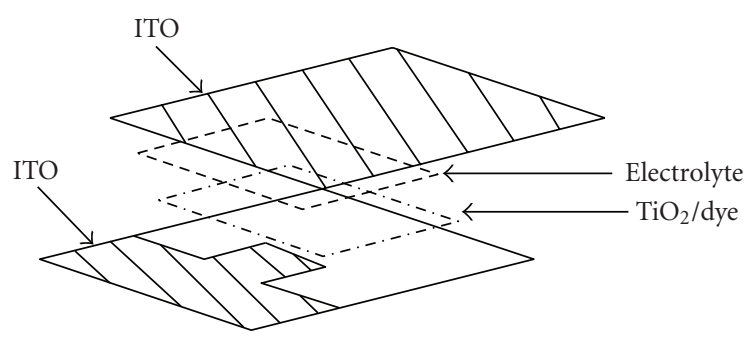

Figure 1: Diagram of PEC cell.

TABLE 1: Electrolytes composition and conductivity at ambient temperature.

\begin{tabular}{lc}
\hline Sample & Conductivity $\left(\mathrm{S} \mathrm{cm}^{-1}\right)$ \\
\hline 55 wt. \% chitosan- 45 wt. $\% \mathrm{NH}_{4} \mathrm{I}$ & $3.73 \times 10^{-7}$ \\
33 wt.\% chitosan-27 wt.\% & $7.34 \times 10^{-6}$ \\
$\mathrm{NH}_{4} \mathrm{I}-40$ wt. $\%$ EC & \\
27.5 wt.\% chitosan-22.5 wt.\% & $3.43 \times 10^{-5}$ \\
$\mathrm{NH}_{4} \mathrm{I}-50$ wt.\% BMII & \\
\hline
\end{tabular}

BMII: Buthyl-methyl-imidazolium-iodide.

An equal area of polymer electrolyte was placed above the $\mathrm{TiO}_{2}$ photoelectrode. Another ITO glass plate (counter electrode) was placed over the whole assembly and clamped with a paper clip. The $J-V$ characteristics of the dye-sensitized solar cells were obtained under white light illumination $\left(100 \mathrm{~mW} \mathrm{~cm}^{-2}\right)$ using a Keithley 2400 electrometer.

The assembly of the fabricated cell is shown in Figure 1.

\section{Results and Discussion}

Table 1 lists the composition of the polymer electrolytes and the respective room temperature conductivity.

Figure 2 shows the plot of $\log$ conductivity versus temperature for each of the electrolyte listed in Table 1. It is noticed in all plots that conductivity increases with temperature. The conductivity-temperature relationship is Arrhenian.

Tables 2 to 4 list the short-circuit current density $J_{\mathrm{sc}}$, open circuit voltage (OCV), fill factor (ff), efficiency $(\eta)$ of PEC cells and the type of polymer electrolyte, redox couple, and dye material used. The photoactive and counter electrodes of all the PEC cells listed are $\mathrm{TiO}_{2}$ and ITO coated with platinum, respectively, except for PEC cells utilizing the chitosan containing electrolyte where the photoactive electrode is $\mathrm{TiO}_{2}$ and the counter electrode is ITO glass without any catalytic material coating.

The conductivity of an electrolyte depends on the ability of the polymer host to solvate the salt. Polymers with higher dielectric constant will serve the purpose better. Apart from that, the lattice energy of the salt should be low since this would help to increase dissociation of the salt. Thus, it may be understood why the different electrolyte systems in Table 2 exhibit different room temperature conductivity. From the results in Table 2, it may be inferred that the dielectric constant of PBA [37] is slightly higher than that 
TABLE 2: Characteristics of PEC cells using polymer-salt systems.

\begin{tabular}{|c|c|c|c|c|c|c|c|c|c|}
\hline Sample & Dye & $\begin{array}{c}\text { Intensity } \\
\left(\mathrm{mW} \mathrm{cm}^{-2}\right)\end{array}$ & $\begin{array}{l}\text { Redox } \\
\text { couple }\end{array}$ & $\sigma\left(\mathrm{S} \mathrm{cm}^{-1}\right)$ & $J_{\mathrm{sc}}\left(\mathrm{mA} \mathrm{cm}^{-2}\right)$ & $\mathrm{OCV}(\mathrm{V})$ & ff & $\eta(\%)$ & Ref. \\
\hline $\begin{array}{l}91 \text { wt. \% Poly(butyl } \\
\text { acrylate) + 9wt.\% NaI }\end{array}$ & $\mathrm{Ru}(\mathrm{dcbpy})_{2}(\mathrm{NCS})_{2}$ & 100 & $\mathrm{I}^{-} / \mathrm{I}_{3}^{-}$ & $2.10 \times 10^{-6}$ & 2.20 & 0.61 & 0.37 & 0.51 & [37] \\
\hline $\begin{array}{l}87.5 \text { wt. } \% \mathrm{PEO}+ \\
12.5 \text { wt. } \% \mathrm{NaI}\end{array}$ & $\mathrm{Ru}(\mathrm{dcbpy})_{2}(\mathrm{NCS})_{2}$ & 100 & $\mathrm{I}^{-} / \mathrm{I}_{3}^{-}$ & $2.02 \times 10^{-6}$ & 1.51 & 0.83 & 0.61 & 0.76 & {$[38]$} \\
\hline $\begin{array}{l}92 \text { wt. } \% \text { PEO + } 8 \text { wt. } \% \\
\text { KI }\end{array}$ & $\operatorname{Ru}(\mathrm{dcbpy})_{2}(\mathrm{NCS})_{2}$ & 100 & $\mathrm{I}^{-} / \mathrm{I}_{3}^{-}$ & $6.33 \times 10^{-5}$ & 5.04 & 0.62 & 0.63 & 1.96 & {$[1]$} \\
\hline $\begin{array}{l}89 \text { wt.\% P(EPI-EO) + } \\
11 \text { wt.\% NaI }\end{array}$ & $\mathrm{Ru}(\mathrm{dcbpy})_{2}(\mathrm{NCS})_{2}$ & 100 & $\mathrm{I}^{-} / \mathrm{I}_{3}^{-}$ & $1.9 \times 10^{-5}$ & 0.55 & 0.75 & - & 0.19 & {$[9]$} \\
\hline $\begin{array}{l}71 \text { wt. } \% \text { P(EPI-EO })+ \\
29 \text { wt. } \% \text { NaI }\end{array}$ & $\operatorname{Ru}(\mathrm{dcbpy})_{2}(\mathrm{NCS})_{2}$ & 120 & $\mathrm{I}^{-} / \mathrm{I}_{3}^{-}$ & $1.0 \times 10^{-5}$ & 0.46 & 0.71 & 0.67 & 0.22 & [39] \\
\hline $\begin{array}{l}55 \text { wt. } \% \text { Chitosan }+ \\
45 \text { wt. } \% \mathrm{NH}_{4} \mathrm{I}\end{array}$ & None & 56.4 & $\mathrm{I}^{-} / \mathrm{I}_{3}^{-}$ & $3.73 \times 10^{-7}$ & 0.005 & 0.15 & 0.22 & - & [35] \\
\hline
\end{tabular}

TABle 3: Characteristics of PEC cells using plasticized polymer-salt systems.

\begin{tabular}{|c|c|c|c|c|c|c|c|c|c|}
\hline Polymer electrolyte Sample & Dye & $\begin{array}{c}\text { Intensity } \\
\left(\mathrm{mW} \mathrm{cm}^{-2}\right)\end{array}$ & Redox couple & $\sigma\left(\mathrm{S} \mathrm{cm}^{-1}\right)$ & $J_{\mathrm{sc}}\left(\mathrm{mA} \mathrm{cm}^{-2}\right)$ & $\begin{array}{l}\mathrm{OCV} \\
(\mathrm{V})\end{array}$ & $\mathrm{ff}$ & $\eta(\%)$ & Ref. \\
\hline $\begin{array}{l}27.2 \text { wt. } \% \text { PEO + } 2.8 \text { wt. } \% \\
\mathrm{Pr}_{4} \mathrm{~N}^{+} \mathrm{I}^{-}+70 \text { wt. } \% \text { EC }\end{array}$ & $\operatorname{Ru}(\text { dcbpy })_{2}(\mathrm{NCS})_{2}$ & 100 & $\mathrm{I}^{-} / \mathrm{I}_{3}^{-}$ & $4.9 \times 10^{-5}$ & 0.051 & 0.44 & 0.48 & 0.01 & {$[40]$} \\
\hline $\mathrm{PEO}+\mathrm{LiI}+\mathrm{EC}+\mathrm{PC}$ & $\operatorname{Ru}(\mathrm{dcbpy})_{2}(\mathrm{NCS})_{2}$ & 27 & $\mathrm{I}^{-} / \mathrm{I}_{3}^{-}$ & $1.2 \times 10^{-3}$ & 2.10 & 0.60 & 0.62 & 2.90 & [41] \\
\hline $\begin{array}{l}13.5 \text { wt. } \% \text { PAN }+7.3 \text { wt. } \% \\
\mathrm{Pr}_{4} \mathrm{~N}^{+} \mathrm{I}^{-}+32.3 \text { wt. } \% \text { EC }+ \\
46.9 \text { wt. } \% \text { PC }\end{array}$ & $\mathrm{Ru}(\mathrm{dcbpy})_{2}(\mathrm{NCS})_{2}$ & 60 & $\mathrm{I}^{-} / \mathrm{I}_{3}^{-}$ & $3.0 \times 10^{-3}$ & 3.73 & 0.69 & - & 2.99 & {$[42]$} \\
\hline $\begin{array}{l}43.5 \text { wt. } \% \mathrm{P}(\mathrm{EPI}-\mathrm{EO})+ \\
13 \text { wt. } \% \mathrm{NaI}+43.5 \text { wt. } \% \\
\mathrm{P}(\mathrm{EGME})\end{array}$ & $\operatorname{Ru}(\text { dcbpy })_{2}(\mathrm{NCS})_{2}$ & 100 & $\mathrm{I}^{-} / \mathrm{I}_{3}^{-}$ & $1.7 \times 10^{-4}$ & 1.88 & 0.7 & - & 0.52 & {$[9]$} \\
\hline $\begin{array}{l}33 \text { wt. } \% \text { chitosan }+ \\
27 \text { wt. } \% \mathrm{NH}_{4} \mathrm{I}+40 \text { wt. } \% \text { EC }\end{array}$ & None & 56.4 & $\mathrm{I}^{-} / \mathrm{I}_{3}^{-}$ & $7.3 \times 10^{-6}$ & 0.007 & 0.22 & 0.18 & - & {$[35]$} \\
\hline
\end{tabular}

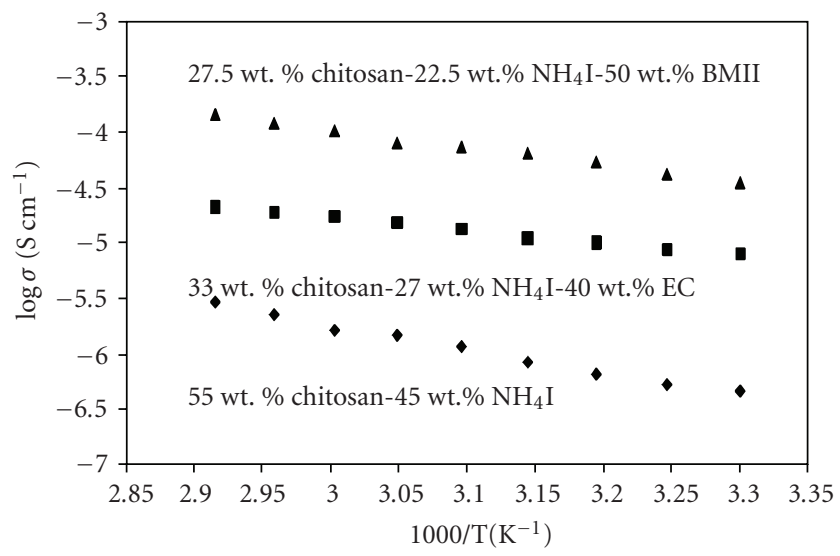

Figure 2: Temperature dependence of ionic conductivity.

of PEO [38] because for a higher salt content in the PEO$\mathrm{NaI}$ electrolyte, the conductivity is almost similar to that of PBA-NaI electrolyte at room temperature (assumed $298 \mathrm{~K}$ ). The composition of the P(EPI-EO)-NaI electrolyte [9] and that of PEO-NaI electrolyte [38] are almost similar. However, the P(EPI-EO)-NaI electrolyte exhibits a conductivity of almost one order of magnitude higher than that of PEO-NaI electrolyte. This has been attributed to the presence of $\mathrm{Cl}$ in $\mathrm{P}(\mathrm{EPI}-\mathrm{EO})$ that played a part in reducing the crystallinity of the polymer $[45,46]$, thus resulting in higher conductivity.

Again referring to Table 2, the composition of the PEO$\mathrm{KI}$ electrolyte [1] is almost similar to the composition of PBA-NaI electrolyte [37], but the conductivity of the former is more than one order of magnitude higher. Although it has been inferred that the dielectric constant of PBA is slightly higher than PEO, the higher conductivity of the PEO-KI electrolyte may be attributed to the lower lattice energy of $\mathrm{KI}$ compared to that of $\mathrm{NaI}$ (according to calculations performed using the Kapunstinskii and Born-Haber equations). Hence, assuming temperature to be the same, the number density of mobile cations is higher in the PEO-KI electrolyte than that in the PBA-NaI electrolyte resulting in a higher conductivity. Another example from Table 2 showing the fact that lower lattice energy of salt results in higher conductivity can be observed from the conductivity of the PEO-KI and PEO-NaI electrolyte systems. At almost similar composition, higher conductivity was observed in the PEO-KI electrolyte compared to PEO-NaI electrolyte. The lattice energy of KI is $614.5 \mathrm{~kJ} \mathrm{~mol}^{-1}$ and that of $\mathrm{NaI}$ is $674 \mathrm{~kJ} \mathrm{~mol}^{-1}$. The lower conductivity of P(EPI-EO)-based electrolyte with $29 \mathrm{wt} . \%$ $\mathrm{NaI}$ compared to the same polymer-based electrolyte with $11 \mathrm{wt} . \% \mathrm{NaI}$ has been attributed to ion pairs formation 
TABLE 4: Characteristics of PEC cells using polymer-salt-ionic liquid systems.

\begin{tabular}{|c|c|c|c|c|c|c|c|c|c|}
\hline Polymer electrolyte Sample & Dye & $\begin{array}{c}\text { Intensity } \\
\left(\mathrm{mW} \mathrm{cm}^{-2}\right)\end{array}$ & $\begin{array}{l}\text { Redox } \\
\text { couple }\end{array}$ & $\sigma\left(\mathrm{S} \mathrm{cm}^{-1}\right)$ & $\begin{array}{c}J_{\mathrm{sc}} \\
\left(\mathrm{mA} \mathrm{cm}^{-2}\right) \\
\end{array}$ & $\mathrm{OCV}(\mathrm{V})$ & $\mathrm{ff}$ & $\eta(\%)$ & Ref. \\
\hline $\begin{array}{l}52.5 \text { wt. } \% \text { PEO + } 17.5 \text { wt. } \% \\
\text { KI + } 30 \text { wt. } \% \text { EMImTFSI }\end{array}$ & $\mathrm{Ru}(\mathrm{dcbpy})_{2}(\mathrm{NCS})_{2}$ & 100 & $\mathrm{I}^{-} / \mathrm{I}_{3}^{-}$ & $8.82 \times 10^{-5}$ & 4.02 & 0.77 & 0.56 & 1.75 & {$[43]$} \\
\hline $\begin{array}{l}15 \text { wt. } \% \text { PEO }+5 \text { wt. } \% \text { KI + } \\
80 \text { wt. } \% \text { EMISCN }\end{array}$ & $\operatorname{Ru}(\mathrm{dcbpy})_{2}(\mathrm{NCS})_{2}$ & 27 & $\mathrm{I}^{-} / \mathrm{I}_{3}^{-}$ & $2.25 \times 10^{-5}$ & 1.89 & 0.65 & 0.52 & 0.63 & {$[44]$} \\
\hline $\begin{array}{l}17.5 \text { wt. } \% \text { PEO + } 2.5 \text { wt. } \% \\
\text { NaI + } 80 \text { wt. } \% \text { EMImTFO }\end{array}$ & $\mathrm{Ru}(\mathrm{dcbpy})_{2}(\mathrm{NCS})_{2}$ & 60 & $\mathrm{I}^{-} / \mathrm{I}_{3}^{-}$ & $4.72 \times 10^{-5}$ & 5.65 & 0.79 & 0.55 & 2.45 & [38] \\
\hline $\begin{array}{l}27.5 \text { wt. } \% \text { Chitosan }+ \\
22.5 \text { wt. } \% \mathrm{NH}_{4} \mathrm{I}+50 \text { wt. } \% \\
\text { BMII }\end{array}$ & $\begin{array}{l}\text { Anthocyanin from } \\
\text { black rice }\end{array}$ & 100 & $\mathrm{I}^{-} / \mathrm{I}_{3}^{-}$ & $3.43 \times 10^{-5}$ & 0.065 & 0.23 & 0.22 & - & - \\
\hline $\begin{array}{l}27.5 \text { wt. } \% \text { Chitosan }+ \\
22.5 \text { wt. } \% \mathrm{NH}_{4} \mathrm{I}+50 \text { wt. } \% \\
\text { BMII }\end{array}$ & $\begin{array}{l}\text { Betalain from } \\
\text { callus of Celosia } \\
\text { plumosa }\end{array}$ & 100 & $\mathrm{I}^{-} / \mathrm{I}_{3}^{-}$ & $3.43 \times 10^{-5}$ & 0.029 & 0.14 & 0.22 & - & - \\
\hline
\end{tabular}

and cross linking sites that hinder segmental motion of the polymer chains thereby decreasing ionic mobility and consequently conductivity [9].

The lower OCV and $J_{\text {sc }}$ exhibited by the cell utilizing the chitosan- $\mathrm{NH}_{4} \mathrm{I}$ electrolyte are probably due to the smaller number of photoelectrons injected into the conduction band of the $\mathrm{TiO}_{2}$. In the absence of a catalyst coating such as $\mathrm{Pt}$ in the counter electrode leads to a slower rate of $\mathrm{I}_{3}{ }^{-}$reduction to $\mathrm{I}^{-}$. This delays the photocurrent and photovoltage generation that accounts for the low $J_{\text {sc }}$ and OCV [35]. According to Yen et al. [47] the $\mathrm{I}_{3}{ }^{-}+2 \mathrm{e}^{-} \rightarrow 3 \mathrm{I}^{-}$ reaction rate is extremely slow if the ITO counter electrode is not coated with catalytic materials.

From Table 3, conductivity for the electrolyte $43.5 \mathrm{wt} . \%$ $\mathrm{P}(\mathrm{EPI}-\mathrm{EO})+43.5$ wt.\% $\mathrm{P}(\mathrm{EGME})+13$ wt.\% NaI [9] is nine times higher than that of the unplasticized electrolyte 89 wt.\% P(EPI-EO) + 11 wt.\% NaI; see Table 2. The employment of poly(ethylene glycol) methyl ether has resulted in more salt to dissociate resulting in a higher conductivity. The conductivity of the PAN $+\mathrm{Pr}_{4} \mathrm{NI}+\mathrm{EC}+\mathrm{PC}$ electrolyte [42] is greater than the conductivity of $\mathrm{PEO}+\mathrm{Pr}_{4} \mathrm{NI}+\mathrm{EC}[40]$ by almost 2 orders of magnitude. This could be attributed to the higher dielectric constant of PAN which is 6.27 [48] compared to that of PEO which is 5 [49] and to the presence of the PC plasticizer. With addition of plasticizer to the chitosan- $\mathrm{NH}_{4} \mathrm{I}$ electrolyte, the conductivity has increased to more than one order of magnitude.

The incorporation of ionic liquid to the electrolytes (Table 4) also improved performance of the PEC cell as shown in the work of Singh et al. [38]. The incorporation of 1-ethyl-3-methylimidazolium trifluoromethanesulfonate (EMImTFO) in the PEO-NaI electrolyte has increased the conductivity from $2.02 \times 10^{-6} \mathrm{~S} \mathrm{~cm}^{-1}$ to $4.72 \times$ $10^{-5} \mathrm{~S} \mathrm{~cm}^{-1}$. An increase by a factor of $\sim 4$ in $J_{\mathrm{sc}}$ of DSSC was found. The PEC cell employing chitosan-based electrolyte also showed increment in conductivity and in $J_{\mathrm{sc}}$. The anthocyanin pigment $\mathrm{pH}$ is also an important factor affecting $J_{\mathrm{sc}}$. In this work, anthocyanin extracted from black rice produced a $65 \mu \mathrm{A} \mathrm{cm}^{-2} J_{\mathrm{sc}}$ and the cell employing the betalain pigment extracted from callus of Celosia plumosa

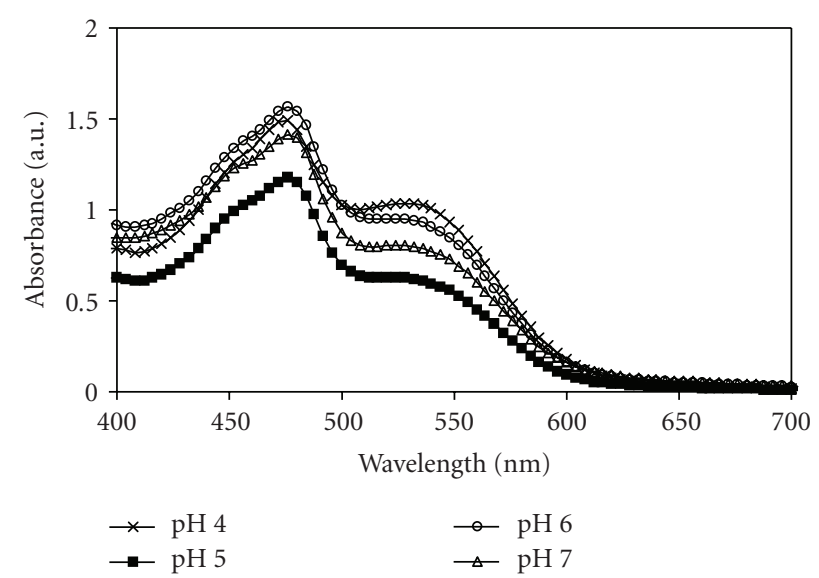

Figure 3: The absorption spectra of betalain at different $\mathrm{pH}$.

$[50,51]$ produced $29 \mu \mathrm{Acm}^{-2} J_{\mathrm{sc}}$. The absorbance of the betalain pigment solution depends on its $\mathrm{pH}$, as shown in Figure 3.

Rahman et al. [5] investigated the effect of electrolyte conductivity on OCV and $J_{\text {sc }}$ of the ITO/TiO $/$ PVC$\mathrm{LiClO}_{4} /$ graphite solar cell. They have shown that both OCV and $J_{\text {sc }}$ increase with electrolyte conductivity. From Table 2, the short-circuit current density $J_{\mathrm{sc}}$ for the PEC cell with PBA-NaI electrolyte is about 1.5 times larger than that of the solar cell employing PEO-NaI electrolyte. The PBA-NaI electrolyte also exhibits higher conductivity compared to PEONaI electrolyte. An almost similar situation can be observed in the work of Nogueira and coworkers [9, 39]. The solar cell utilizing the lower conducting electrolyte $71 \mathrm{wt}$ \% P(EPIEO)-29 wt.\% NaI exhibits a short-circuit current density that is smaller than the solar cell utilizing the higher conducting electrolyte 89 wt.\% P(EPI-EO)-11 wt.\% NaI. This implies that higher conductivity of the electrolyte results in higher $J_{\text {sc }}$ of the solar cell. However, the DSSCs employing PBA-NaI [37] and PEO-NaI [38] electrolytes with lower conductivity exhibit higher $J_{\mathrm{sc}}$ compared to the cells using P(EPI-PEO)NaI electrolytes $[9,39]$. The DSSCs utilizing PBA-NaI and 


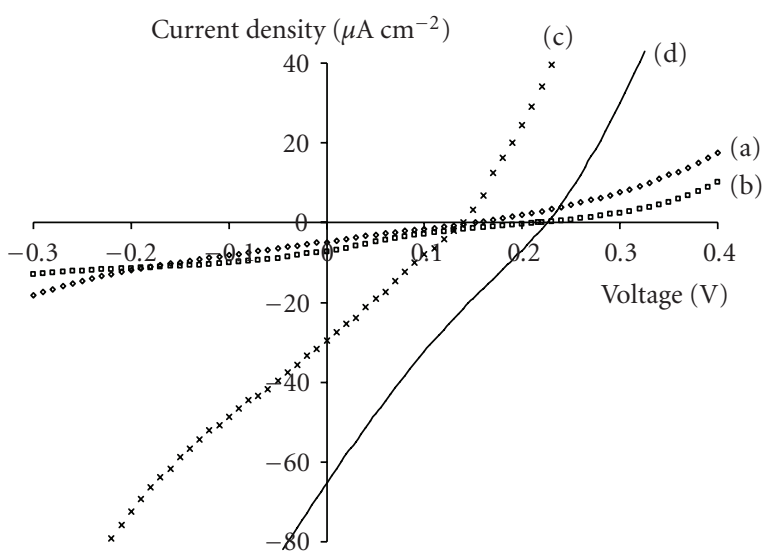

FIgURE 4: Current density versus voltage characteristics under illumination for (a) $\mathrm{ITO} / \mathrm{TiO}_{2} / 55 \mathrm{wt} . \%$ chitosan $+45 \mathrm{wt} . \% \mathrm{NH}_{4} \mathrm{I} /$ ITO, (b) ITO/ $\mathrm{TiO}_{2} / 33$ wt. $\%$ chitosan +27 wt. $\% \quad \mathrm{NH}_{4} \mathrm{I}+40$ wt. $\% \mathrm{EC} /$ ITO, (c) ITO/TiO $/$ betalain dye (callus of Celosia plumosa)/ 27.5 wt. $\%$ chitosan +22.5 wt. $\% \quad \mathrm{NH}_{4} \mathrm{I}+50 \mathrm{wt} . \% \mathrm{BMII} / \mathrm{ITO}$, and (d) $\mathrm{ITO} / \mathrm{TiO}_{2}$ /anthocyanin dye (black rice) $/ 27.5 \mathrm{wt} . \%$ chitosan +22.5 wt.\% $\mathrm{NH}_{4} \mathrm{I}+50$ wt.\% BMII/ITO.

PEO-NaI electrolyte have an extra layer coated on the ITO glass beneath the $\mathrm{TiO}_{2}$ semiconducting photoelectrode layer. This underlayer consists of Ti(IV)bis(ethyl acetoacetato)diisopropoxide coating. According to these authors, the Ti(IV)bis(ethyl acetoacetato)-diisopropoxide coating suppresses electron back recombination to the oxidized electrolyte. It is not clear from literature whether the DSSCs employing $\mathrm{P}(\mathrm{EPI}-\mathrm{EO})-\mathrm{NaI}$ electrolyte have this underlayer coating. If this is the case, it may be understood why the $J_{\mathrm{sc}}$ exhibited by these DSSCs is lower when the conductivity of the electrolyte is about one order of magnitude higher than the PBA-NaI and PEO-NaI electrolyte. The recombination is more evident in the absence of the underlayer leading to a depletion of the number of free electrons flowing through the external circuit resulting in a low $J_{\text {sc }}$. The low OCV exhibited by the cells using the chitosan electrolyte is probably due to the small difference in Fermi level of the $\mathrm{TiO}_{2}$ and Fermi level of the redox couple. Figure 4 shows the plot of current density versus voltage characteristics for DSSC employing electrolytes of 55 wt. $\%$ chitosan +45 wt. $\% \mathrm{NH}_{4} \mathrm{I}, 33 \mathrm{wt} . \%$ chitosan +27 wt. $\% \mathrm{NH}_{4} \mathrm{I}+40 \mathrm{wt} . \% \mathrm{EC}$, and $27.5 \mathrm{wt} . \%$ chitosan +22.5 wt. $\% \mathrm{NH}_{4} \mathrm{I}+50$ wt. $\%$ BMII.

\section{Conclusions}

Ethylene carbonate and ionic liquid enhance the conductivity of the electrolyte with chitosan as polymer host and $\mathrm{NH}_{4} \mathrm{I}$ as doping salt. $\log \sigma$ versus $\mathrm{T}$ dependence follows the Arhenius rule. Betalain pigment from calli of Celosia plumosa and anthocyanin pigment from black rice can serve as dye in solid-state solar cell applications. It was found that the dielectric constant of polymer and lattice energy of salt influence the conductivity. The conductivity in turn affects the short-circuit current density of the solar cells.

\section{Acknowledgments}

The authors thank the University of Malaya and M. H. Buraidah thanks the SLAB scheme for financial support.

\section{References}

[1] G. P. Kalaignan, M.-S. Kang, and Y. S. kang, "Effects of compositions on properties of $\mathrm{PEO}-\mathrm{KI}-\mathrm{I}_{2}$ salts polymer electrolytes for DSSC," Solid State Ionics, vol. 177, no. 11-12, pp. 10911097, 2006.

[2] T. Yohannes, T. Solomon, and O. Inganäs, "Polymerelectrolyte-based photoelectrochemical solar energy conversion with poly(3-methylthiophene) photoactive electrode," Synthetic Metals, vol. 82, no. 3, pp. 215-220, 1996.

[3] S. A. Mohamad, R. Yahya, Z. A. Ibrahim, and A. K. Arof, "Photovoltaic activity in a $\mathrm{ZnTe} / \mathrm{PEO}$-chitosan blend electrolyte junction," Solar Energy Materials and Solar Cells, vol. 91, no. 13, pp. 1194-1198, 2007.

[4] B. Bhattacharya, H. M. Upadhyaya, and S. Chandra, "Photoelectrochemical studies of an ion conducting polymer (PEO)/semiconductor (Si) junction," Solid State Communications, vol. 98, no. 7, pp. 633-638, 1996.

[5] M. Y. A. Rahman, M. M. Salleh, I. A. Talib, and M. Yahaya, "Effect of ionic conductivity of a $\mathrm{PVC}-\mathrm{LiClO}_{4}$ based solid polymeric electrolyte on the performance of solar cells of ITO/TiO $/ \mathrm{PVC}_{2} \mathrm{LiClO}_{4} /$ graphite," Journal of Power Sources, vol. 133, no. 2, pp. 293-297, 2004.

[6] Y. Yang, C. Zhou, S. Xu, et al., "Improved stability of quasisolid-state dye-sensitized solar cell based on poly (ethylene oxide)-poly (vinylidene fluoride) polymer-blend electrolytes," Journal of Power Sources, vol. 185, no. 2, pp. 1492-1498, 2008.

[7] J. Wu, P. Li, S. Hao, H. Yang, and Z. Lan, "A polyblend electrolyte ( $\left.\mathrm{PVP} / \mathrm{PEG}+\mathrm{KI}+\mathrm{I}_{2}\right)$ for dye-sensitized nanocrystalline $\mathrm{TiO}_{2}$ solar cells," Electrochimica Acta, vol. 52, no. 17, pp. 53345338, 2007.

[8] O. A. Ileperuma, M. A. K. L. Dissanayake, S. Somasunderam, and L. R. A. K. Bandara, "Photoelectrochemical solar cells with polyacrylonitrile-based and polyethylene oxide-based polymer electrolytes," Solar Energy Materials and Solar Cells, vol. 84, no. 1-4, pp. 117-124, 2004.

[9] V. C. Nogueira, C. Longo, A. F. Nogueira, M. A. Soto-Oviedo, and M.-A. De Paoli, "Solid-state dye-sensitized solar cell: improved performance and stability using a plasticized polymer electrolyte," Journal of Photochemistry and Photobiology A, vol. 181, no. 2-3, pp. 226-232, 2006.

[10] M. Matsumoto, H. Miyazaki, K. Matsuhiro, Y. Kumashiro, and Y. Takaoka, "A dye sensitized $\mathrm{TiO}_{2}$ photoelectrochemical cell constructed with polymer solid electrolyte," Solid State Ionics, vol. 89, no. 3-4, pp. 263-267, 1996.

[11] Z. Lan, J. Wu, D. Wang, S. Hao, J. Lin, and Y. Huang, "Quasisolid state dye-sensitized solar cells based on gel polymer electrolyte with poly(acrylonitrile-co-styrene)/NaI $+\mathrm{I}_{2}$," Solar Energy, vol. 80, no. 11, pp. 1483-1488, 2006.

[12] O. A. Ileperuma, M. A. K. L. Dissanayake, and S. Somasundaram, "Dye-sensitised photoelectrochemical solar cells with polyacrylonitrile based solid polymer electrolytes," Electrochimica Acta, vol. 47, no. 17, pp. 2801-2807, 2002.

[13] P. K. Singh, K.-W. Kim, N.-G. Park, and H.-W. Rhee, "Mesoporous nanocrystalline $\mathrm{TiO}_{2}$ electrode with ionic liquidbased solid polymer electrolyte for dye-sensitized solar cell application," Synthetic Metals, vol. 158, no. 14, pp. 590-593, 2008. 
[14] J.-M. Philias and B. Marsan, "All-solid-state photoelectrochemical cell based on a polymer electrolyte containing a new transparent and highly electropositive redox couple," Electrochimica Acta, vol. 44, no. 17, pp. 2915-2926, 1999.

[15] S. A. Mohamad, M. H. Ali, R. Yahya, Z. A. Ibrahim, and A. K. Arof, "Photovoltaic activity in a ZnSe/PEO-chitosan blend electrolyte junction," Ionics, vol. 13, no. 4, pp. 235-240, 2007.

[16] T. Yohannes and O. Inganaäs, "Photoelectrochemical studies of the junction between poly[3-(4-octylphenyl)thiophene] and a redox polymer electrolyte," Solar Energy Materials and Solar Cells, vol. 51, no. 2, pp. 193-202, 1998.

[17] A. Kambili, A. B. Walker, F. L. Qiu, A. C. Fisher, A. D. Savin, and L. M. Peter, "Electron transport in the dye sensitized nanocrystalline cell," Physica E, vol. 14, no. 1-2, pp. 203-209, 2002.

[18] A. Fukui, R. Komiya, R. Yamanaka, A. Islam, and L. Han, "Effect of a redox electrolyte in mixed solvents on the photovoltaic performance of a dye-sensitized solar cell," Solar Energy Materials and Solar Cells, vol. 90, no. 5, pp. 649-658, 2006.

[19] Z. Lan, J. Wu, D. Wang, S. Hao, J. Lin, and Y. Huang, "Quasisolid-state dye-sensitized solar cells based on a sol-gel organicinorganic composite electrolyte containing an organic iodide salt," Solar Energy, vol. 81, no. 1, pp. 117-122, 2007.

[20] S. Yanagida, G. K. R. Senadeera, K. Nakamura, T. Kitamura, and Y. Wada, "Polythiophene-sensitized $\mathrm{TiO}_{2}$ solar cells," Journal of Photochemistry and Photobiology A, vol. 166, no. 13, pp. 75-80, 2004.

[21] H. Santa-Nokki, S. Busi, J. Kallioinen, M. Lahtinen, and J. Korppi-Tommola, "Quaternary ammonium polyiodides as ionic liquid/soft solid electrolytes in dye-sensitized solar cells," Journal of Photochemistry and Photobiology A, vol. 186, no. 1, pp. 29-33, 2007.

[22] A. Sergawie, T. Yohannes, and T. Solomon, "A comparative study on liquid-state photoelectrochemical cells based on poly(3-hexylthiophene) and a composite film of poly(3hexylthiophene) and nanocrystalline titanium dioxide," Synthetic Metals, vol. 157, no. 2-3, pp. 75-79, 2007.

[23] Z. Lan, J. Wu, J. Lin, M. Huang, P. Li, and Q. Li, "Influence of ionic additives $\mathrm{NaI} / \mathrm{I}_{2}$ on the properties of polymer gel electrolyte and performance of quasi-solid-state dye-sensitized solar cells," Electrochimica Acta, vol. 53, no. 5, pp. 2296-2301, 2008.

[24] M. G. Kang, K. S. Ryu, S. H. Chang, and N.-G. Park, "A new ionic liquid for a redox electrolyte of dye-sensitized solar cells," ETRI Journal, vol. 26, no. 6, pp. 647-652, 2004.

[25] M. A. Butler and D. S. Ginley, "Principles of photoelectrochemical, solar energy conversion," Journal of Materials Science, vol. 15, no. 1, pp. 1-19, 1980.

[26] S. A. Sapp, C. M. Elliott, C. Contado, S. Caramori, and C. A. Bignozzi, "Substituted polypyridine complexes of cobalt(II/III) as efficient electron-transfer mediators in dyesensitized solar cells," Journal of the American Chemical Society, vol. 124, no. 37, pp. 11215-11222, 2002.

[27] S. K. Deb, "Dye-sensitized $\mathrm{TiO}_{2}$ thin-film solar cell research at the national renewable energy laboratory (NREL)," Solar Energy Materials and Solar Cells, vol. 88, no. 1, pp. 1-10, 2005.

[28] Q. Dai, D. B. Menzies, D. R. MacFarlane, et al., "Dyesensitized nanocrystalline solar cells incorporating ethylmethylimidazolium-based ionic liquid electrolytes," Comptes Rendus Chimie, vol. 9, no. 5-6, pp. 617-621, 2006.

[29] M. Grätzel, "Dye-sensitized solar cells," Journal of Photochemistry and Photobiology C, vol. 4, no. 2, pp. 145-153, 2003.
[30] Q. Dai and J. Rabani, "Photosensitization of nanocrystalline $\mathrm{TiO}_{2}$ films by anthocyanin dyes," Journal of Photochemistry and Photobiology A, vol. 148, no. 1-3, pp. 17-24, 2002.

[31] S. Hao, J. Wu, Y. Huang, and J. Lin, "Natural dyes as photosensitizers for dye-sensitized solar cell," Solar Energy, vol. 80, no. 2, pp. 209-214, 2006.

[32] E. Yamazaki, M. Murayama, N. Nishikawa, N. Hashimoto, M. Shoyama, and O. Kurita, "Utilization of natural carotenoids as photosensitizers for dye-sensitized solar cells," Solar Energy, vol. 81, no. 4, pp. 512-516, 2007.

[33] M. Gorlov and L. Kloo, "Ionic liquid electrolytes for dyesensitized solar cells," Dalton Transactions, no. 20, pp. 26552666, 2008.

[34] M. H. Buraidah, L. P. Teo, S. R. Majid, and A. K. Arof, "Ionic conductivity by correlated barrier hopping in $\mathrm{NH}_{4} \mathrm{I}$ doped chitosan solid electrolyte," Physica B, vol. 404, no. 8-11, pp. 1373-1379, 2009.

[35] M. H. Buraidah, L. P. Teo, S. R. Majid, and A. K. Arof, "Characteristics of $\mathrm{TiO}_{2}$ /solid electrolyte junction solar cells with $I^{-} / I_{3}^{-}$redox couple," Optical Materials, vol. 32, no. 6, pp. 723-728, 2009.

[36] R. M. Taha, "Tissue culture studies of Citrus hystrix D.C and Severinia buxifolia (Poir) Tenore," Asia-Pacific Journal of Molecular Biology and Biotechnology, vol. 1, no. 1, pp. 36-42, 1993.

[37] J. H. Kim, M.-S. Kang, Y. J. Kim, J. Won, and Y. S. Kang, "Poly(butyl acrylate)/NaI/I $/ \mathrm{I}_{2}$ electrolytes for dye-sensitized nanocrystalline $\mathrm{TiO}_{2}$ solar cells," Solid State Ionics, vol. 176, no. 5-6, pp. 579-584, 2005.

[38] P. K. Singh, K.-W. Kim, and H.-W. Rhee, "Development and characterization of ionic liquid doped solid polymer electrolyte membranes for better efficiency," Synthetic Metals, vol. 159, no. 15-16, pp. 1538-1541, 2009.

[39] A. F. Nogueira and M. De Paoli, "Dye sensitized $\mathrm{TiO}_{2}$ photovoltaic cell constructed with an elastomeric electrolyte," Solar Energy Materials and Solar Cells, vol. 61, no. 2, pp. 135$141,2000$.

[40] T. M. W. J. Bandara, M. A. K. L. Dissanayake, O. A. Ileperuma, K. Varaprathan, K. Vignarooban, and B.-E. Mellander, "Polyethyleneoxide (PEO)-based, anion conducting solid polymer electrolyte for PEC solar cells," Journal of Solid State Electrochemistry, vol. 12, no. 7-8, pp. 913-917, 2008.

[41] Y. Ren, Z. Zhang, S. Fang, M. Yang, and S. Cai, "Application of PEO based gel network polymer electrolytes in dye-sensitized photoelectrochemical cells," Solar Energy Materials and Solar Cells, vol. 71, no. 2, pp. 253-259, 2002.

[42] M. A. K. L. Dissanayake, L. R. A. K. Bandara, R. S. P. Bokalawala, P. A. R. D. Jayathilaka, O. A. Ileperuma, and S. Somasundaram, "A novel gel polymer electrolyte based on polyacrylonitrile (PAN) and its application in a solar cell," Materials Research Bulletin, vol. 37, no. 5, pp. 867-874, 2002.

[43] P. K. Singh, K.-W. Kim, and H.-W. Rhee, "Electrical, optical and photoelectrochemical studies on a solid PEO-polymer electrolyte doped with low viscosity ionic liquid," Electrochemistry Communications, vol. 10, no. 11, pp. 1769-1772, 2008.

[44] B. Bhattacharya, S. K. Tomar, and J. K. Park, "A nanoporous $\mathrm{TiO}_{2}$ electrode and new ionic liquid doped solid polymer electrolyte for dye sensitized solar cell application," Nanotechnology, vol. 18, pp. 485711-485714, 2007.

[45] M. A. Silva, M.-A. De Paoli, and M. I. Felisberti, "Phase behavior of poly(ethylene oxide)/poly(epichlorohydrin) blends," in Proceedings of 4 th Simposio Latinoamericano de Polimeros, pp. 440-442, Gramado, Brazil, 1994. 
[46] G. Goulart Silva, N. H. T. Lemes, C. N. Polo da Fonseca, and M.-A. De Paoli, "Solid state polymeric electrolytes based on poly(epychlorhydrin)," Solid State Ionics, vol. 93, pp. 105-116, 1996.

[47] M.-Y. Yen, C.-Y. Yen, S.-H. Liao, et al., "A novel carbon-based nanocomposite plate as a counter electrode for dye-sensitized solar cells," Composites Science and Technology, vol. 69, no. 13, pp. 2193-2197, 2009.

[48] W. Lu, J.-B. Peng, K.-X. Yang, L.-F. Lan, Q.-L. Niu, and Y. Cao, "Polymer thin-film transistor based on a high dielectric constant gate insulator," Chinese Physics, vol. 16, no. 4, pp. 1145-1149, 2007.

[49] M. Kumar and S. S Sekhon, "Role of plasticizer's dielectric constant on conductivity modification of $\mathrm{PEO}-\mathrm{NH}_{4} \mathrm{~F}$ polymer electrolytes," European Polymer Journal, vol. 38, no. 7, pp. 1297-1304, 2002.

[50] W. Schliemann, Y. Cai, T. Degenkolb, J. Schmidt, and H. Corke, "Betalains of Celosia argentea," Phytochemistry, vol. 58, no. 1, pp. 159-165, 2001.

[51] D. Strack, T. Vogt, and W. Schliemann, "Recent advances in betalain research," Phytochemistry, vol. 62, no. 3, pp. 247-269, 2003. 


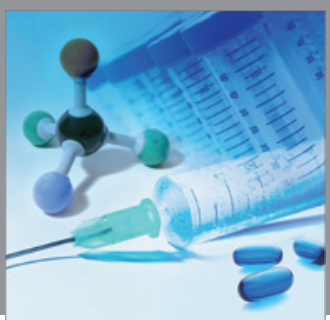

International Journal of

Medicinal Chemistry

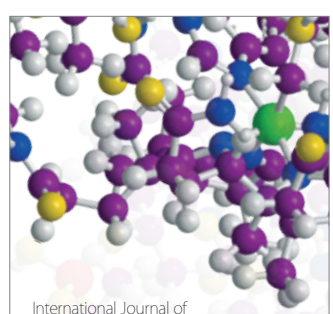

Carbohydrate Chemistry

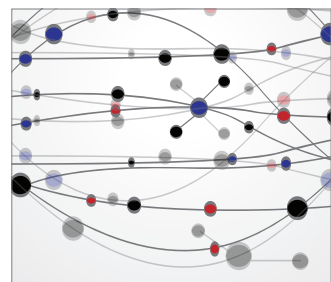

The Scientific World Journal
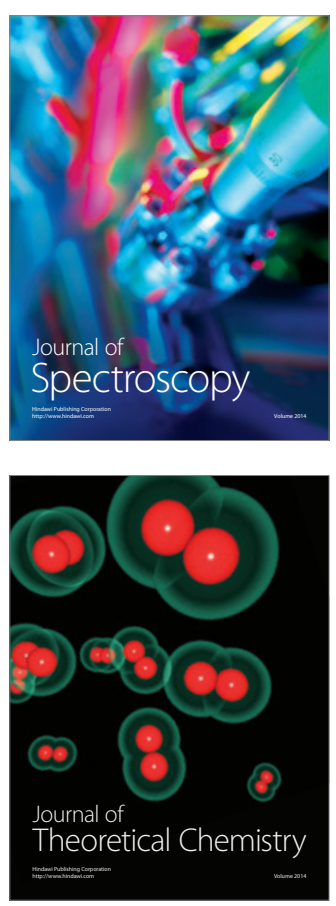
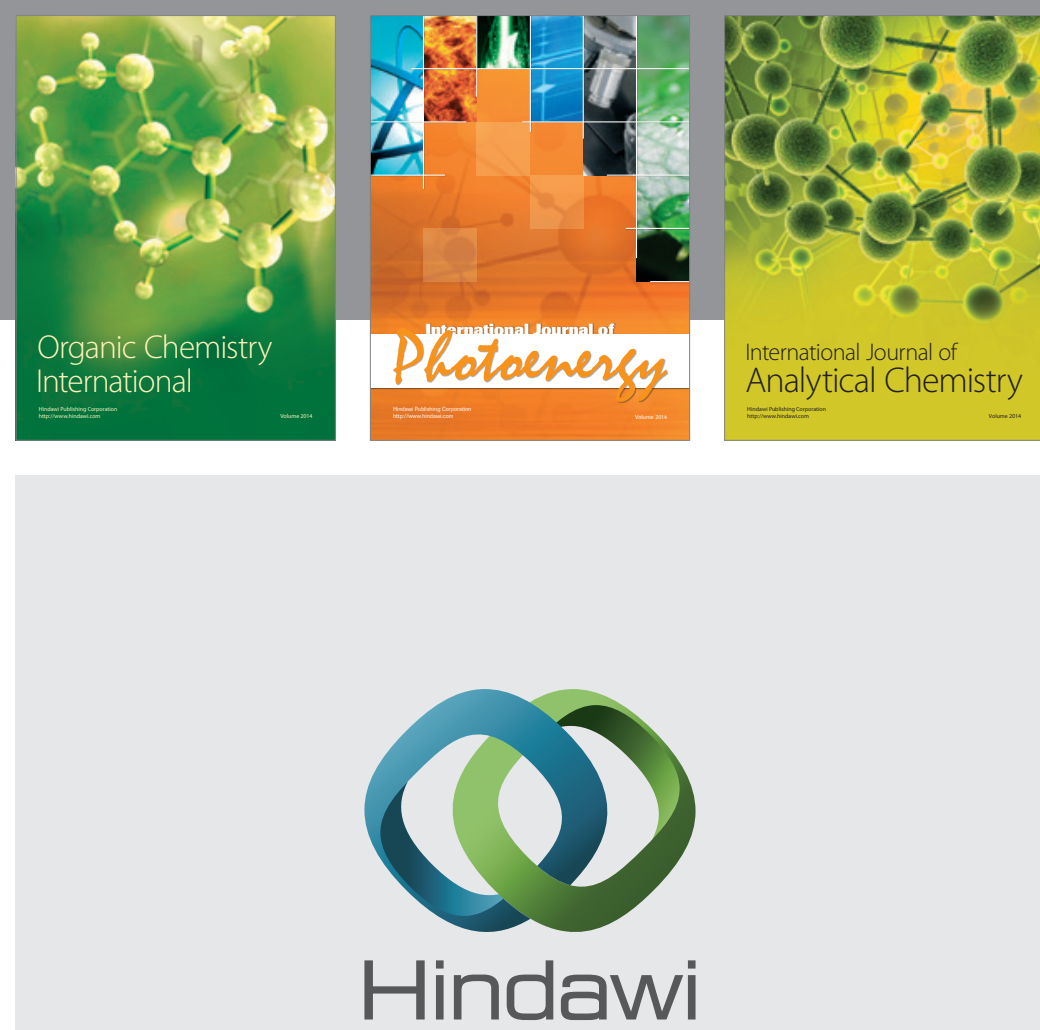

Submit your manuscripts at

http://www.hindawi.com
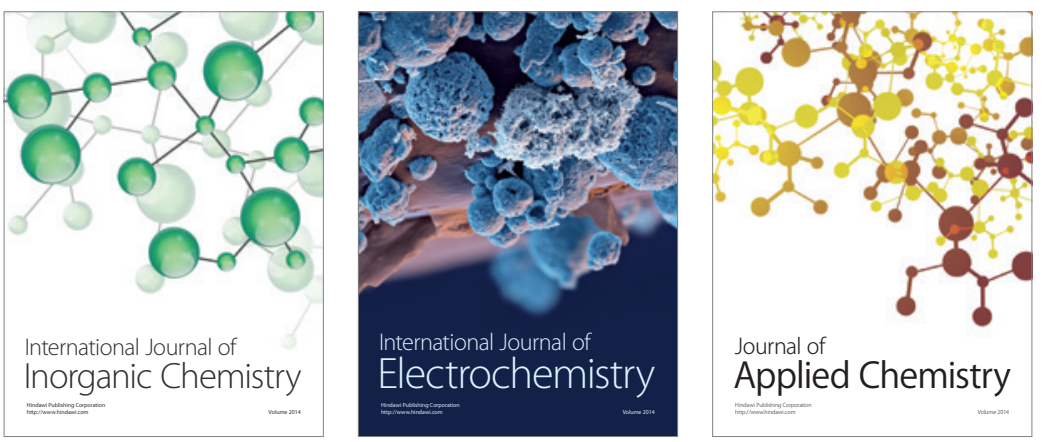

Journal of

Applied Chemistry
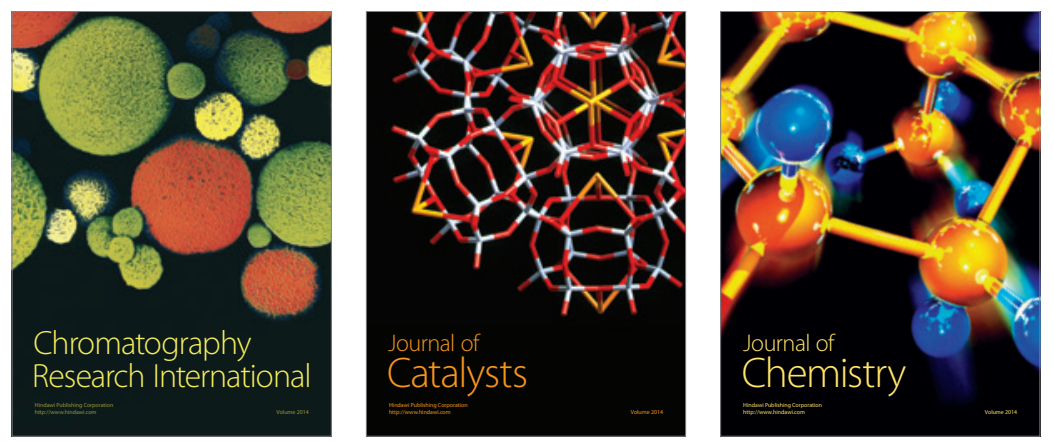
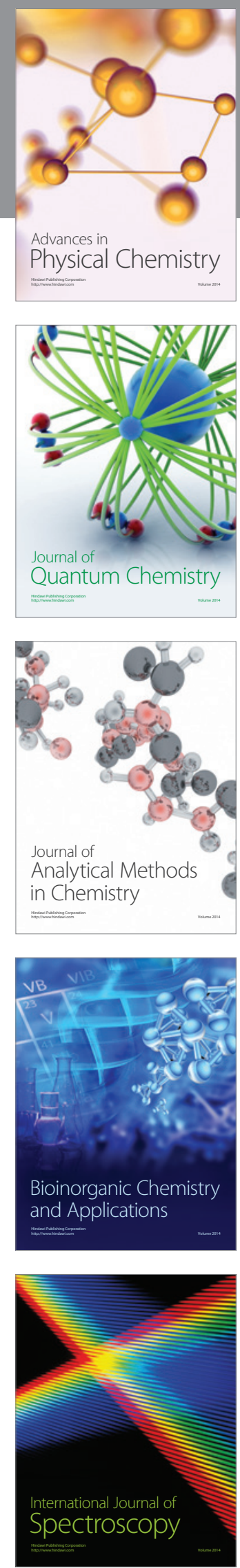